\title{
Ortak Kısıtlı Rota Kapsama Problemlerinin Çözümü İçin Melez Genetik Algoritma Yaklaşımı
}

\section{A Hyrid Genetic Algorithm Approach for Solving Partner Constrained Lane Covering Problems}

\author{
Gültekin Kuyzu 1,2*(D)
}

1 TOBB Ekonomi ve Teknoloji Üniversitesi, Mühendislik Fakültesi, Endüstri Mühendisliği Bölümü, Ankara, TÜRKIYE 2 Zaragoza Logistics Center, Zaragoza, İSPANYA

Sorumlu Yazar / Corresponding Author*: gkuyzu@etu.edu.tr

\author{
Geliş Tarihi / Received: 11.07.2019 Araștırma Makalesi/Research Article \\ Kabul Tarihi / Accepted: 13.11.2019 10.21205/deufmd.2020226509 \\ Atıf șekli/ How to cite: KUYZU, G.(2020). Ortak Kısıtlı Rota Kapsama Problemlerinin Çözümü için Melez Genetik Algoritma Yaklaşımı. \\ DEUFMD, 22(65), 401-416.
}

\section{Öz}

Ortak Kısıtlı Rota Kapsama Problemleri (OKRKP’ler) tam kamyon yükü hizmeti satın alma işbirliği ağlarında ortaya çıkan NP-Zor ayrıt rotalama problemleridirler. Bu problemlerde amaç, işbirliği yapan birden fazla gönderici firmanın tam kamyon yükü gönderi rotalarını, birden fazla gönderici firmadan gönderi rotası ve boş kamyon hareketleri içerebilecek ve göndericilerin çevrim paylaşmak istediği azami ortak sayılarını aşmadan kapsayan en kısa toplam uzunluklu yönlü çevrimler kümesini bulmaktır. Bu makale, OKRKP'lerin çözümü için geliştirilen; genetik algoritma, yerel arama ve geniş komşuluk arama yaklașımlarının birleșiminden oluşan bir melez genetik algoritma (MGA) yaklaşımını sunmaktadır. Bu yaklaşım, NP-Zor RKP'lerin çözümü için önerilen ilk meta-sezgisel çözüm yaklaşımıdır. Önerilen MGA, daha önce literatürdeki çalışmalarda kullanılan problem örnekleri üzerinde denenmiștir. Deneylerde kullanılan büyük ölçekli problem örneklerinin önemli bir kısmında bilinen en iyi çözümlerden daha iyi çözümler elde edilmiştir.

Anahtar Kelimeler: rota kapsama problemi, ayrıt rotalama, melez genetik algoritma

\begin{abstract}
Partner Constrained Lane Covering Problems (PCLCPs) are NP-Hard arc routing problems arising in collaborative truckload transportation procurement networks. The objective in these problems is to cover a set of full truckload shipment lanes of multiple shippers using cyles, each of which may include lanes from different shippers and empty truck movements, with minimum total cost such that each shipper does not share cycles with more than a prespecified number of partners. This paper presents a hybrid genetic algorithm (HGA) approach that combines genetic algorithm, local search and large neighborhood search approaches for solving PCLCPs. This approach is the first meta-heuristic that has been proposed for solving NP-Hard LCPs. The proposed MGA has been tested on instances that were previously used in the literature. It has improved the previous best known solutions of a significant portion of the large scale instances that were tested.

Keywords: lane covering problem, arc routing, hybrid genetic algorithm
\end{abstract}




\section{Giriş}

Rota Kapsama Problemi (RKP, LCP: Lane Covering Problem) lojistik ve tedarik zincirinde artarak görülen kurumlar arası yatay ișbirliğinin bir türü olan, işbirlikli tam kamyon yükü hizmeti satın alma ağlarından ortaya çıkan bir ayrıt rotalama problemidir. $\mathrm{Bu}$ ağlarda, taşıyıcı firmalardan taşımacılık hizmeti alan bir grup gönderici firma bir araya gelir; ve grup halinde taşıyıcı firmalara avantajlı rota kombinasyonları sunarak daha düşük maliyetli taşımacılık hizmeti satın almaya çalışırlar [1][2] .

İşbirliği yapan göndericiler boş kamyon hareketlerini en küçüklemeyi amaçlayan sürekli hareketler veya turlar kurdukları için taşıyıcı firmaların maliyetlerini azaltmış olurlar. Bunun yanında, özellikle düzenli olarak tekrarlanan turlar taşıyıcı firmaların en büyük problemlerinden olan sürücü devrim oranının azaltılmasına da yardımcı olurlar. Sürücü devrim oranının yüksek olmasında en önemli nedenler olarak; sürücülerin zamanlarının büyük bir bölümünü evlerinden ve ailelerinden uzakta geçirmeleri ve gidecekleri güzergahları önceden bilmemelerinden doğan düzensizlik olarak gösterilmektedirler. Sürücülerin yapacağı seferlerin düzenli olması, evlerinde ve aileleriyle düzenli olarak zaman geçirmelerini sağlamakta ve iş memnuniyetini artırmaktadır. Bu avantajlar nedeniyle işbirliği yapan gönderici firmalar taşıyıcı firmalardan daha düşük fiyatlar alabilmektedirler.

İşbirliğine dahil edilecek göndericilerin seçimi genelde rota birleştirme çözümüne bırakılmaktadır. Burada, çok sayıda ve çeşitli sektörlerden düzenli gönderi rotası bir araya getirilir. Burada amaç birbirini tamamlayan rotalar bulma olasılı̆̆ını mümkün olduğu kadar yüksek tutmaktır. Sonrasında, toplam maliyeti en aza indirmek amacıyla hangi düzenli gönderi rotalarının arka arkaya eklenerek turlar oluşturacağına karar verilir. Rota birleştirme çözümünde rotalarının hiçbiri diğer göndericilerin rotaları ile birleştirilmeyen göndericiler işbirliği dışında kalmış varsayılır. Düzenli gönderi turlarından oluşan çözümün toplam maliyeti ile firmaların başlangıçtaki bireysel maliyetlerinin toplamı arasındaki fark, işbirliğinden elde edilecek toplam maliyet kazanımını verir.

Gönderici ișbirliği ağlarında boș kamyon hareketlerini en aza indirecek turların bulunması kolay değildir. Ağdaki üye sayısı ve dolayısıyla da hesaba katılması gereken tam kamyon yükü gönderi rotalarının sayısı arttıkça, değerlendirilmesi gereken muhtemel tur sayısı üssel olarak artar ve en iyileme teknolojisine ihtiyaç duyulur.

\subsection{Rota kapsama problemleri}

Tam kamyon yükü gönderici işbirliğinde altta yatan temel optimizasyon problemi Rota Kapsama Problemi (RKP, LCP: Lane Covering Problem) olarak tanımlanmıştır. Daha matematiksel bir dille ifade etmek gerekirse; RKP, yönlü çizge $G=(N, A)$ ve ayrıt uzunlukları $f_{a}$ $(a \in A)$ ile tanımlanan şebekede yönlü ayrıtların düzenli gönderileri temsil eden bir alt kümesini $(L \subseteq A)$ kapsayan ve uzunlukları toplamı en kısa olan yönlü çevrimler kümesini bulma problemi olarak tanımlanır. Bu haliyle RKP, bir akış dolaşım problemine dönüştürülerek polinom zamanda çözülebilir. Ancak, kapsamada kullanılabilecek çevrimlere bazı kısıtların getirilmesiyle ortaya çıkan RKP varyantlarını çözmek çok daha zordur. Mesela, kullanılacak herhangi bir yönlü çevrimde yer alabilecek rota ayrıtı sayısına bir üst sınır getirilmesiyle oluşan Sayı KIsitlı RKP (SKRKP, CCLCP: Cardinality Constrained $L C P$ ) ve yine kullanılacak herhangi bir yönlü çevrimde yer alabilecek ayritların uzunlukları toplamına bir üst sınır getiren Uzunluk Kisitli RKP (UKRKP, LCLCP: Length Constrained LCP) NP-Zor problemlerdir. Aynı zamanda, her çevrimin tamamlanma süresine bir üst sınır ve rotalar için zaman pencereleri kısıtları koyan Zaman Kısıtlı RKP (ZKRKP, TCLCP: Time Constrained LCP) da NP-Zor bir problemdir. SKRKP, UKRKP ve ZKRKP'ye en iyi çözüm bulmak için; ilgili problemde tanımlanan kısıtları ihlal etmeyen olurlu çevrimlerin tamamı üzerinde tanımlanacak bir küme kapsama formülasyonu kullanılabilir. Ancak, rota ayrıtı sayısı arttıkça olurlu çevrimlerin sayısının üssel hızda büyümesi nedeniyle, büyük ölçekli problem örneklerinin etkin şekilde çözümü için sezgisel yöntemler önerilmiştir [1][2].

Gerçek hayat uygulamalarında karşılaşılabilecek bir başka durum ise bir göndericinin ișbirliği içinde olacağl gönderici sayısının sınırlanmasıdır. İşbirliği çeşitli iş süreçlerini etkiler ve yönetilmesi gereken yeni ilişki ve bağlantılar doğurur. $\mathrm{Bu}$ nedenle, gönderici firmalar işbirliği ortaklarını sınırlı sayıda tutmak isteyebilirler. $\mathrm{Bu}$ basit gibi görünen sınırlama 
altta yatan en iyileme probleminin karmașıklığını ciddi biçimde etkiler ve bir bașka NP-Zor RKP varyantını ortaya çıkarır. Bu varyant Ortak Kısıtlı RKP (OKRKP) olarak adlandırılmıștır [3].

OKRKP'nin matematiksel dille tanımı: $N$ düğüm kümeli ve $A$ ayrıt kümeli yönlü çizge $G=(N, A)$, ve ayrıt uzunlukları $f_{a}(a \in A)$ ile tanımlanan bir şebeke ve her firmaya ait rotaları temsil eden $L_{i}$ $\subseteq A, i=1, \ldots, P$ rota kümeleri verildiğinde $L=L_{1} \cup \ldots$ $\cup L_{P}$ rota ayritlar kümesini kapsayan, ve ayrica bir rota kümesi $L_{i}^{\prime}$ yi kapsayan çevrimlerin diğer rota kümelerinden $\left(\left\{L_{j}: j \neq i\right\}\right)$ en fazla $k_{i}$ tanesinden rota ayrıtı içeren ve uzunlukları toplamı en küçük olan yönlü çevrimler kümesinin bulunmasıdır.

Ergun vd. [1], tam kamyon yükü gönderici işbirliği ağlarında en düşük toplam maliyetli işbirlikli çözümü bulma amacından hareketle, RKP'yi literatüre kazandırmış, UKRKP ve SKRKP varyantlarının NP-Zor olduğunu göstermiş ve SKRKP için sezgisel yöntemler geliştirmişlerdir. Geliştirilen sezgisel; düşük oranda boş kamyon hareketi içeren çevrimlerin enumerasyonu, elde edilen çevrimlerin dolu hareket mesafe yüzdeleri azalacak şekilde sıralanması ve daha sonra aynı rota ayrıtının birden fazla çevrimle kapsanmamasını sağlayacak şekilde çözüme eklenmesinden olușur.

Aynı yazarlar başka bir çalışmalarında [2] ZKRKP'yi çalıșmış ve çözümü için bütün rota ayrıtlarının tek başlarına ayrı ayrı çevrimlerde olduğu çözümden başlayarak, çevrimleri azgözlü bir şekilde tekrar tekrar birleștirilmesinden (bkz. Șekil 9) olușan bir sezgisel geliștirmișlerdir. Bu sezgiselin performansını Ergun vd. [1] tarafından geliștirilen sezgisel ile karşılaştırmışlar ve daha iyi sonuçlar elde ettiğini ortaya koymuşlardır. Söz konusu sezgisel, araç rotalama problemleri literatüründe sıkça kullanılan Clarke-Wright [4] (tasarruf) sezgiseline oldukça benzemektedir. Temel farkı, her iterasyonda tek bir birleştirme işlemi yerine birden fazla birleștirme yaparak rota ayrıtlarının nihai çözümdeki çevrimlere daha dengeli şekilde dağıtmayı amaçlamasıdır.

Immorlica vd. [5]; Ergun vd. [1] gibi, SKRKP için düşük oranda boş kamyon hareketi içeren çevrimlerin enumerasyonu ile elde edilen çevrimler arasından dual-giydirme (dual-fitting) yöntemi ile seçim yaparak çözümde yer alacak çevrimleri belirler. Önerilen yöntemin SKRKP için $(1+\ln 2)$ faktör yaklaşıklık değerine sahip olduğunu göstermişlerdir.

Kuyzu [3]; OKRKP'yi literatüre kazandırmış; sayı, uzunluk ve/veya ortak kısıtlarını içerebilen RKP'lerin çözümünde kullanılabilecek sütun türetme ve dal-fiyat yaklaşımları önermiştir. $\mathrm{Bu}$ çözüm yaklaşımlarının ilk aşamalarında, Ergun vd. [2] tarafından geliștirilen açgözlü çevrim birleștirme sezgiseli uygulanmaktadır ve elde edilen çözümler sütun türetmenin başlangıç çevrimler kümesine dahil edilmektedir. Bu nedenle bu yöntemlerin açgözlü çevrim birleștirme sezgiselinden daha kötü bir çözüm elde etme ihtimalleri yoktur. Deneysel çalışmalarda açgözlü birleştirme sezgiselinden çok daha iyi sonuçlar elde etmișlerdir. Sütun türetme ve dal-fiyat yaklaşımlarının, özellikle problem boyutu büyüdügünde kaba-kuvvet yaklaşımına göre daha etkin oldukları gözlenmiştir.

\section{2. Çizgelerde çevrim kapsama problemleri}

RKP, verilen bir çizgedeki ayrıtların bir alt kümesinin çevrimlerle belirli amaç ve kısıtlar doğrultusunda kapsanmasını içermektedir. Literatürde çizgelerin çevrimleri ile kapsanmasını konu alan çalışmalar mevcuttur. Thomassen [6] bir çizgenin bütün ayrıtlarını kapsayan en küçük toplam uzunluklu çevrimler kümesini bulmanın NP-Zor olduğunu göstermiștir. Hochbaum ve Olinick [7] sınırlı çevrim kapsama problemi için, başka problemler için geliştirilen çözüm yöntemlerine dayanan, sezgisel çözüm yöntemleri geliștirmișlerdir. Fernandes vd. [8] minimum çevrim kapsama probleminin güçlü bağlı ve sınırlı ağaç genișliğine sahip karma çizgelerde polinom zamanda çözülebileceğini göstermişlerdir.

\subsection{Ayrit rotalama problemleri ve genetik algoritmalar}

Kısıtlı RKP varyantları Kapasiteli Ayrit Rotalama Problemi (KARP, CARP Capacitated Arc Routing Problem) [9] ile yakından ilgilidirler. Ancak, KARP'tan farklı olarak turların başlangıç ve bitiş noktalarını teşkil edecek depo(lar) içermezler. Bu nedenle, kisıtlı RKP varyantları KARP'ın bir gevşetmesi olarak değerlendirilebilirler.

Corberán ve Prins [10], KARP'ların çözümü için önerilen yöntemlerin bir derlemesini sunmuşlardır. KARP'ların çözümünde, problemi (araç rotalama problemi gibi) eşdeğer bir Düğüm Rotalama Problemine (DRP, NRP: Node Routing 
DEÜ FMD 22(65), 401-416, 2020

Tablo 1. Bu çalışmanın literatürde bulunan NP-Zor RKP'ler üzerine yapılan çalışmalar ile karşılaştırılması

\begin{tabular}{|c|c|c|c|c|c|}
\hline \multirow{3}{*}{ RKP Referans } & \multicolumn{4}{|c|}{ RKP Kısitı } & \multirow[b]{3}{*}{ Çözüm Yöntemi } \\
\hline & & Uzunlu & & & \\
\hline & Sayı & $\mathrm{k}$ & Zaman & Ortak & \\
\hline Ergun vd. [1] & $\checkmark$ & $(\sqrt{ })$ & & & Çevrim enumerasyonu, açgözlü seçim sezgisel \\
\hline Immorlica vd. [5] & $\checkmark$ & $(\sqrt{ })$ & & & Çevrim enumerasyonu, dual giydirme \\
\hline Ergun vd. [2] & & $(\sqrt{ })$ & $\checkmark$ & & Açgözlü birleștirme sezgiseli \\
\hline Kuyzu [3] & $(\sqrt{ })$ & $(\sqrt{ })$ & & $\checkmark$ & Sütun türetme, dal-fiyat \\
\hline Bu çalışma & $(\sqrt{ })$ & $(\sqrt{ })$ & & $\checkmark$ & MGA \\
\hline
\end{tabular}

$\checkmark$ : Birincil odak $(\checkmark)$ : İkincil odak

Problem) dönüştürmek ve elde edilen DRP ile çalışmak sıklıkla bașvurulan bir yaklașımıdır. Literatürde, çeşitli KARP'lar ve DRP'ler için çok sayıda Genetik Algoritma (GA) tabanlı çözüm yaklaşımı önerilmiştir. Bu yaklaşımların GA ve yerel arama stratejilerini bir arada içeren Melez Genetik Algoritmalar (MGA'lar) oldukları dikkat çekmektedir. MGA'lar, birden fazla en iyileme yaklaşımının sinerjik birleşimini içermeleri nedeniyle Memetik Algoritma (MA) olarak da adlandırılmaktadırlar [11].

Lacomme vd. [12], KARP ve birden fazla amacı da içeren bazı uzantılarının çözümü için bir MGA önermişlerdir. Prins [13], Araç Rotalama Problemi (VRP) ve bazı uzantılarının çözümü için bir MGA yaklașımı sunmuș ve denektașı (benchmark) problem örnekleri üzerinde o zamana kadar VRP için en başarılı çözüm yaklaşımı olan Tabu Arama yaklaşımından daha etkin çalıștığını ortaya koymuştur. Prins [14], başka bir çalışmasında, Heterojen VRP'ler için iki ayrı MGA yaklaşımı önermiș ve çok sayıda denektaşı problem örneğinin bilinen en iyi çözümlerini iyileștirmiștir. Liu vd. [15], tașıyıcı bir firmanın müşterilerinden sipariş aldığı tam kamyon yükü gönderilerinden hangilerini kendi aracı ile taşıyacağını hangilerini işbirliği yaptığı taşıyıcı firmalara taşıtacağına karar vermesine yardımcı olacak bir Tercihli (selective) KARP'ın çözümü için bir MGA önermişlerdir. Chen vd. [16] KARP'ın denektaşı problem örnekleri için bilinen en iyi sonuçları veya daha iyi sonuçları kısa sürede elde eden bir MGA sunmuşlardır. Arakaki ve Usberti [17], araçların başladığı yere dönme zorunluluğunun olmadığı Açık KARP için bir MGA önermişlerdir. Tirkolaee vd. [18], kentlerde çöp toplama işlemlerinin çevreye etkisini en aza indirgeme hedefinden ortaya çıkan Çok-Seferli (multi-trip) Yeşil KARP için bir MGA önermişlerdir. Hiermann vd. [19]; standart içten yanmalı motorlu, şarj edilebilir melez motorlu ve sadece elektrikli motorlu araçların bir arada kullanılabildiği bir VRP tanımlamıș ve çözümü için bir MGA önermişlerdir.

Bir önceki paragrafta atıf yapılan çalışmaların tamamında kromozomlar, turların sınırlarını belirtmeden, sadece ayritların permütasyonu şeklinde kodlanmışlardır. Turların sınırları, Ulusoy'un çalışmasında [20] ilk defa önerdiği gibi, permütasyonun tanımladığı dev turun (giant tour) en kısa yol probleminin çözülmesinde kullanılanlara benzer algoritmalar yoluyla parçalanmasına dayanan yöntemiyle dolaylı olarak belirlenmişlerdir. Bu çalışmaların, Tirkolaee vd. [18] hariç olmak üzere, bir bașka ortak özelliği ise GA çerçevesinde mutasyon yerine (2-opt gibi) yerel iyileștirme mekanizmalarını kullanmalarıdır. Tirkolaee vd. [18] ise, başlangıç populasyonundaki çözümleri bir çözüm inşa algoritması ve tavlama benzetimi yoluyla üretmiş ve daha sonra klasik GA uygulamışlardır. Chen vd. [16] tarafindan önerilen yöntem, yerel iyileștirme dışında rastgele tabu eşik ve olursuz iniş (descent) prosedürleri içerir. Hiermann vd. [19] tarafından önerilen yaklaşım ise, geniş komşuluk arama (GKA) [21] tarzl tahrip ve tamir operasyonlarının her iterasyonda sadece birer defa uygunlanmasını içerir.

\subsection{Bu çalışmanın literatüre katkısı}

Bu çalışmada, Kuyzu[3] tarafından OKRKP'lerin ve genel olarak sayı ve/veya uzunluk kısıtlarını içerebilen OKRKP varyantlarının çözümü için önerilen, sütun türetme ve dal-fiyat yaklaşımlarına alternatif olacak genetik 
algoritma tabanlı melez bir meta-sezgisel çözüm yaklașımı önerilmektedir. Sayı kısıtı, SKRKP'deki gibi, kullanılacak herhangi bir yönlü çevrimde yer alabilecek rota ayrıtı sayısına bir üst sınır getirir. Uzunluk kısitı ise, UKRKP'deki gibi, kullanılacak herhangi bir yönlü çevrimde yer alabilecek ayritların uzunlukları toplamına bir üst sınır getirir. Genetik algoritma, mutasyon yerine yerel arama kullanılması ve mevcut popülasyondaki bireylerin GKA tarzı tahrip ve tamir operasyonlarıyla dönüştürülmesi suretiyle melezleștirilmiștir. Bu herhangi bir NP-Zor RKP varyantı için geliştirilmiş ilk meta-sezgisel olma özelliğini tașımaktadır (bkz. Tablo 1). Metasezgisel, daha önce Kuyzu [3] tarafından rastgele olușturulmuș OKRKP örnekleri üzerinde denenmiş ve yine Kuyzu[3] tarafından bu problem örnekleri üzerinde elde edilen sonuçlarla karșılaștırılarak daha kısa sürede yüksek kalitede çözümler elde edebileceği gösterilmiştir. Bazı problem örnekleri için bilinen en iyi çözümlerden daha iyi çözümler elde edilmiştir.

Bu makalenin devamında, Bölüm 2'de problemin çözümü için daha önce önerilen bir tam sayılı programlama modeli yer almaktadır. Problem için geliștirilen melez genetik algoritma Bölüm 3'te anlatılmaktadır. Bölüm 4'te önerilen yöntemin bașarımının hesaplamalı deneyler yoluyla değerlendirilmesine ilişkin sonuçlar verilmektedir. Son olarak, Bölüm 5'te ise yapılan çalışmaya ilişskin bulgular özetlenmektedir.

\section{Matematiksel Model}

Bu bölümde Kuyzu [3] tarafindan OKRKP ve varyantlarının kesin en iyi çözümünü bulmak için önerilen karma tam sayılı programlama modeli verilmektedir. Bu model, bütün olurlu basit çevrimler kümesi üzerinden tanımlanmıștır.

\section{Kümeler:}

$N$ : Dügümler kümesi,

$A$ : Ayritlar kümesi,

$L \quad$ : Rota ayrıtları kümesi $(L \subseteq A)$,

$P \quad$ : Gönderici firmalar kümesi,

$L_{i} \quad$ : Gönderici firma $i \in P$ için rota ayrıtları kümesi,
$C(L)$ : En az bir rota ayrıtı içeren olurlu çevrimler kümesi.

\section{Parametreler:}

$F_{c} \quad: c$ çevriminin uzunluğu, $\forall c \in C(L)$

$s_{l c}: l$ rota ayrıtı, $c$ çevriminin içindeyse 1 , diğer duruma 0 değerini alır, $\forall l \in L, c \in$ $C(L)$,

$p_{c i j}: c$ çevrimi, $\{i, j\}$ gönderici firma çiftinin her ikisinden birden rota ayrıtı içeriyorsa 1, diğer durumda 0 değerini alır, $\forall c \in$ $C(L),\{i, j\} \subseteq P$

$k_{i}$ : Gönderici firma i'nin işbirliği içinde olmak istediği maksimum firma sayısı, $\forall i \in P$,

$M \quad$ : Yeterince büyük bir sayı.

\section{Karar değişkenleri:}

$x_{c}: c$ çevrimi seçildiğinde 1 , diğer durumda 0 değerini alır, $\forall c \in C(L)$

$y_{i j}$ : Seçilen çevrimlerden en az biri $\{i, j\}$ gönderici firma çiftinin her ikisinden birden rota ayrıtı içeriyorsa 1 , diğer durumda 0 değerini alır, $\forall\{i, j\} \subseteq P$.

\section{Formülasyon:}

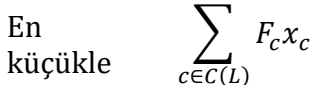

Öyle ki:

$$
\begin{array}{cc}
\sum_{c \in C(L)} s_{l c} x_{c}=1 \quad \forall l \in L \\
\sum_{c \in C(L)} p_{c i j} x_{c} \leq M y_{i j} & \forall\{i, j\} \subseteq P \\
\sum_{j \in P \backslash\{i\}} y_{i j} \leq k_{i} & \forall i \in P \\
x_{c} \in\{0,1\} & \forall c \in C(L) \\
y_{i j} \in\{0,1\} & \forall\{i, j\} \subseteq P
\end{array}
$$

Yukarıdaki formülasyonda, amaç (1) seçilen çevrimlerin uzunlukları toplamını en küçükler. Kısıt (2) her rota ayrıtının tam olarak bir çevrim 
tarafından kapsanmasını sağlar. Kısıt (3) $i$ ve $j$ gönderici firmalarından her ikisinden birden rota ayrıtı içeren en az bir çevrim seçilmesi halinde $y_{i j}$ karar değișkeninin 1 değerini almasını sağlar. Kısıt (4) $i$ gönderici firmasının en fazla $k_{i}$ farklı gönderici firma ile çevrim paylaşmasını sağlar. Kısıtlar (5) ve (6) tam sayı kısıtlarıdırlar.

OKRKP'ye sayl, uzunluk ve/veya zaman kısıtlarının eklenmesi halinde, yukarıdaki formülasyon geçerliliğini koruyacaktır. $\mathrm{Bu}$ kısıtlardan herhangi biri eklendiğinde çevrimleri kümesi $C(L)$ daha az sayıda çevrim içerektir.

Yukarıdaki formülasyonda her olurlu çevrim $c \in$ $C(L)$ için bir $x_{c}$ karar değişkeni bulunmaktadır. Problem boyutu büyüdükçe, olurlu çevrim sayısı üssel olarak artmaktadır. Bu nedenle dal-fiyat gibi gelişmiş çözüm yöntemleri veya sezgisel/meta-sezgisel çözüm yaklașımlarına ihtiyaç vardır. Bu çalışmada, genetik algoritma tabanlı melez bir meta-sezgisel geliştirilmiştir. $\mathrm{Bu}$ meta-sezgiselin detayları aşağıda yer almaktadır.

\section{Melez Genetik Algoritma}

$\mathrm{Bu}$ bölümde, bu makalenin temel konusunu teşkil eden, çözülmesi için geliştirilen MGA tanıtılmaktadır. Söz konusu MGA, bașlangıç popülasyonunun olușturulmasından sonra; çaprazlama, yerel arama, geniş komşuluk arama ve yeni neslin seçimi ana adımlarının durma koşulları sağlanıncaya kadar tekrar edilmesinden oluşur (Şekil 1).

\begin{tabular}{|ll|}
\hline Adım 1: & Başlangıç popülasyonunu oluştur \\
Adım 2: & Durma koşulları sağlanıyorsa dur \\
Adım 3: & Çaprazlama ve yerel arama yap \\
Adım 4: & Geniş Komşuluk Arama uygula \\
Adım 5: & Yeni nesli seç \\
Adım 6: & Adım 2'ye git
\end{tabular}

Sekil 1. MGA ana adımları

Bu bölümün devamında MGA'nın ana adımları ayrı alt başlıklar halinde detaylı bir şekilde açıklanmaktadır.

\subsection{Kromozom yapısı ve amaç fonksiyonu değeri hesaplama}

OKRKP için genetik algoritma operasyonlarının gerçekleștirilmesi amacıyla, her çözüm bütün rota ayrıtlarının permütasyonu (yani sıralaması) şeklinde ifade edilerek kromozom yapısı olușturulmaktadır. Bu kromozom yapısı, gezgin satıcı problemi ve araç/ayrıt rotalama problemlerinde sıklıkla kullanılan bir yapıdır. Gezgin satıcı probleminde tek bir tur olușturma zorunluluğu olduğu için görülmese de, birden fazla tur yapmayı zorunlu hale getiren kisitlar nedeniyle araç/ayrıt rotalama problemlerinde bir kromozom birden fazla çözüme karşıllık gelebilmektedir. Yani, tur sinırları belirlenmeden uygunluk ve/veya amaç fonksiyonu değerlerini hesaplamak mümkün değildir. Bunun sonucunda, araç/ayrıt rotalama problemleri için geliştirilen genetik algoritmalarda tur sinırlarının (yani tur başlangıç ve bitiş genlerini) nasıl belirleneceği önemli bir konudur. Tur sınırlarını kromozom yapısı içine dahil ederek takibini yapmak bir alternatif olsa da, çaprazlama sonucu elde edilecek çocukların tur sınırlarının belirlenmesi gibi, bazı problemler içermektedir. Bu nedenle, tur sınırlarını açıkça belirten kromozom yapıları tercih edilmemektedir.

Çözüm kromozomları, tur sınırlarını takip etmeden, sadece basit permütasyonlar olarak ifade edildiğinde, Ulusoy [20] tarafından yine KARP için geliștirilen bir sezgisel algoritmaya dayalı yöntemler kullanılmaktadır. Ulusoy'un algoritması kapasite kısitlarını görmezden gelerek, bütün ayrıtları ziyaret eden dev bir tur olușturur ve daha sonra bu turu ikincil bir yönlü çevrimsiz çizgede bir En Kisa Yol Problemi (EKYP) çözerek alt turlara ayırır. Algoritmanın en iyi çözümü bulma garantisi yoktur, ancak verilen bir dev turu, kromozomdaki son ayritın bir (alt) turun son ayrıtı olması koşuluyla, polinom zamanda en iyi bir șekilde alt turlara ayırmaktadır. KARP ve VRP çeşitleri için geliștirilen genetik algoritmalarda ise, her permütasyon kromozom için en iyi tur sınırlarını belirlemede kullanılmıștır. Olușturulan ikincil çizge çevrim içermediği için, EKYP etiket sabitleme algoritması ile çok hızlı bir şekilde (doğrusal zamanda) çözülebilmektedir. Ulusoy'un algoritmasının en iyi alt turları elde edemediği karmaşık kısıtlar içeren rotalama problemlerinde ise, algoritmada bir takım değișiklikler yaparak ve ikincil algoritmalarla desteklenerek alt turlar elde edilmiștir. Bu sayede çaprazlama ve mutasyon operasyonlarında tur sinırlarını takip etme zarureti ortadan kaldırılmıștır.

Bu çalışmada geliştirilen MGA kapsamında da OKRKP çözümleri basit permütasyon kromozomlar şeklinde kodlanmaktadır. Her alt tur bir çevrime karşıllk gelmektedir ve 
tur/çevrim sinırları takip edilmemektedir. Verilen bir rota ayrıtı permütasyonu için en iyi çevrim sınırlarını belirlemek mümkün olsa da, ortak kısıtları nedeniyle Ulusoy'un çözdüğü EKYP'yi çözerek belirlemek mümkün değildir. En iyi çevrim sınırlarını belirlemek için yine ikincil bir yönlü çevrimsiz çizge (directed acyclic graph) oluşturup bu çizge üzerinde bir Kaynak Kisitlı En Kisa Yol Problemi (KK-EKYP, resource constrained shortest path problem) çözmek mümkündür. Ancak KK-EKYP'nin yönlü çevrimsiz çizgelerde tek bir kaynak çeșidi, bütün ayrit uzunluklarının ve kaynak kullanım miktarlarının pozitif olduğu durumda bile NPZor bir problem olduğu bilinmektedir[22]. KKEKYP'nin tekrar tekrar çözülmesi gerektiği için, her seferinde kesin en iyi çözümü bulacak bir algoritmanın toplam koșturum zamanını negatif etkileme riski yüksektir. $\mathrm{Bu}$ nedenle, bu çalışmada en iyi tur sınırlarını bulma garantisi olmayan fakat hızlı çalışan bir etiket sabitleme algoritması ile tur sınırları belirlenmektedir.

MGA'da kullanılan etiket sabitleme algoritması koșturulmadan önce, verilen bir kromozom için bir yönlü çevrimsiz çizge oluşturulur. Daha sonra bu yönlü çevrimsiz çizge üzerinde ayrit uzunlukları belirlenir ve çevrimler üzerindeki kısıtları sağlamak için gerekli kaynaklar tanımlanır. Hazırlık işlemlerini Şekil 2 ile verilen beş rota ayrıtlı $(L=\{1,2,3,4,5\})$ ve üç göndericili $(P=\{1,2,3\})$ küçük problem örneği (KPÖ) yardımıyla açıklayalım. KPÖ'de rota ayrıtlarının başlangıç ve bitiş noktaları eşit aralıklı (açık gri renkli) kılavuz çizgilerinin kesişim noktalarına yerleştirilmişlerdir. Her rota ayrıtının üzerinde numarası ve ait olduğu göndericinin numarasını içeren bir etiket yer almaktadır. Mesela, "3 (1)" etiketi rota ayritının 3 numaralı rota ayrıtı olduğunu ve 1 numaralı göndericiye ait olduğunu ifade eder. KPÖ için 3-1-2-5-4 kromozomu verilmiș olsun. Cevrim sınırlarının olmadığı veya belirlenmediği durumda, bu kromozom Şekil 3 ile verilen büyük tura karşıllk gelir. Şekilde kesikli çizgileri olan ayrıtlar rota ayrıtları arası boş kamyon hareketini gösterirken, kırmızı kesikli çizgiyle gösterilen ayrıt kromozomdaki son rota ayritı ile ilk rota ayrıtı arasındaki boş kamyon hareketini ifade eder. Çevrimler belirlenirken rota ayrıtlarının kromozomdaki sıralaması korunur ve şekildeki kırmızı ayrıtın dev tur çevrimi dişında kullanılmasına izin verilmez. Hazırlık işlemlerinin son halkası olarak, her rota ayrıtı için bir düğüm ve ek olarak bir adet yapay dügüm içeren gösterilen yönlü çevrimsiz çizge (YÇÇ) oluşturulur (Şekil 4). $B$ bir kromozom olsun ve kromozom $B^{\prime}$ de $i$ 'nci sirada olan rota ayrıtı $B[i]$ ile ifade edilsin $(B[0]=0)$. YÇÇ'deki her $(B[i], B[j])$ ayrıtı, orijinal çizgede (Şekil 2) $B[i+$ $1], \ldots, B[j]$ rota ayrıtlarından oluşan bir çevrime karşılık gelmektedir. Örneğin, $(B[0], B[2])=$ $(0,1)$ ayrıtına karşılık gelen çevrim Şekil 5 ile, $(B[1], B[4])=(3,5)$ ayrıtına karşılık gelen çevrim ise Şekil 6 ile resmedilmiştir. $(0,4)$ ayrıtı ise dev tur çevrimine (Şekil 3) karşıllık gelmektedir. YÇÇ'deki her ayrıtın uzunluğu, o ayrita orijinal çizgede karşılık gelen çevrimin uzunluğuna eşit olur. Olursuz çevrimlere karşıllk gelen ayritlar, yani ortak sayısı kısıtları veya varsa uzunluk ve rota ayrıtı sayısı gibi kısıtları ihlal eden ayrıtlar, YÇÇÇden silinir. Böylece, YÇÇ’de sadece olurlu çevrimler kümesi $C(L)$ içinde olan çevrimlere karșılık gelen ayrıtlar kalır. Örneğin, KPÖ'de gönderici 3 en fazla bir gönderici ile çevrim paylaşmak istiyorsa, yani $k_{3}=1$ ise; $(0,5),(0,4),(3,5),(3,4)$, ve $(1,4)$ ayrıtları YÇÇ’'den silinirler. Etiket sabitleme algoritması, nihai YÇÇ üzerinde 0 düğümünden 4 düğümüne (son düğüm) gönderici firmaların ortak sayısı kısıtlarını aşmayan en iyi veya en iyiye yakın en kısa yolu bulmayı amaçlar.

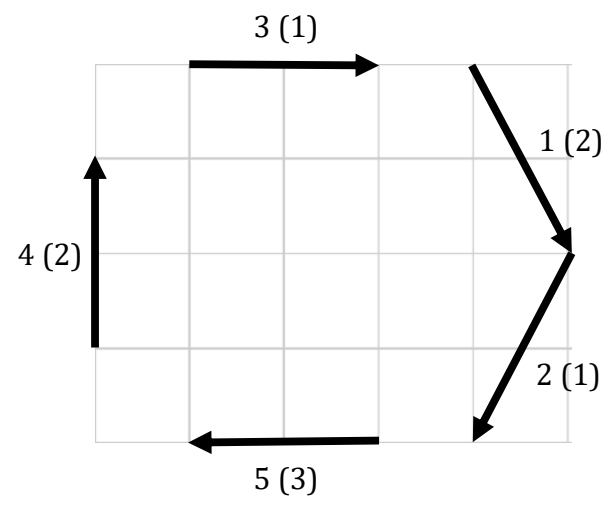

Şekil 2. Beş rota ayrıtlı $(L=\{1,2,3,4,5\})$ ve üç göndericili $(P=\{1,2,3\})$ küçük problem örneği (KPÖ). 


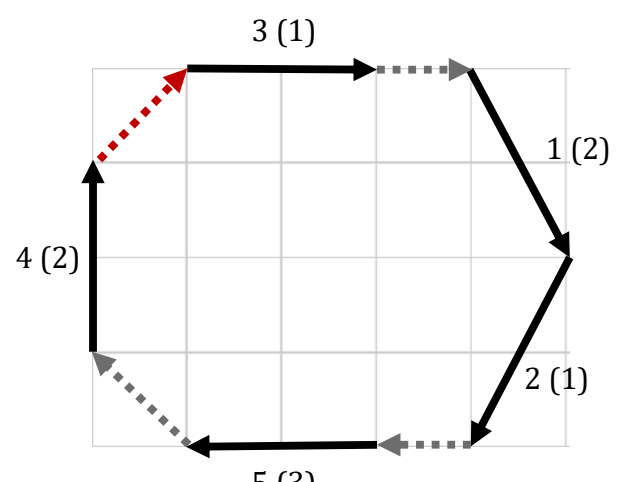

$5(3)$

Şekil 3. KPÖ için 3-1-2-5-4 kromozomuna karşılık gelen dev tur çevrimi.

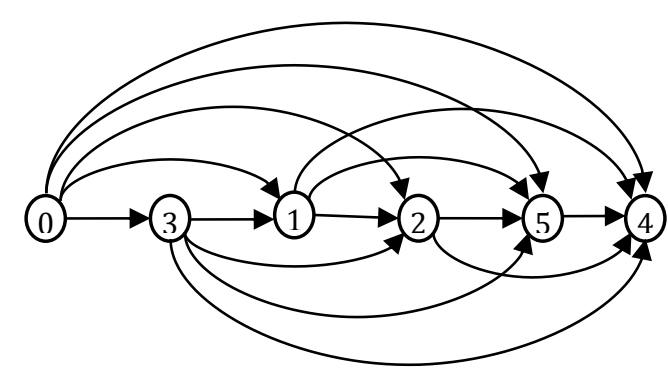

Şekil 4. KPÖ ve 3-1-2-5-4 kromozomu için çevrim/tur sınırlarını belirlemede kullanılacak yönlü çevrimsiz çizge (YÇÇ).

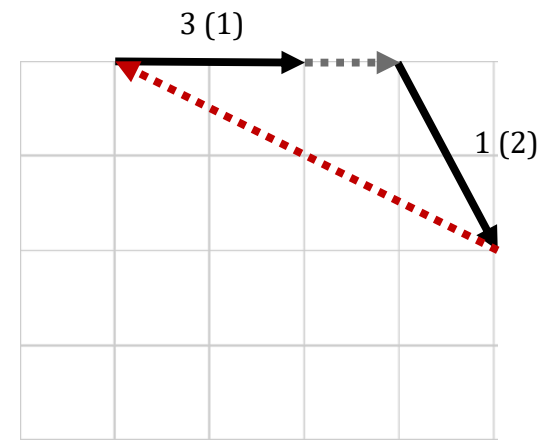

Şekil 5. YÇÇ’de $(0,1)$ ayrıtına karşıllık gelen çevrim.

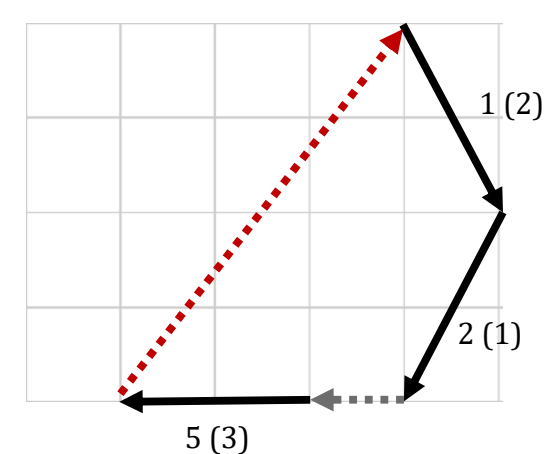

Şekil 6. YÇÇ'de $(3,5)$ ayrıtına karşılık gelen çevrim.

Kullanılan etiket sabitleme algoritmasının adımları Şekil 7'de sıralanmıștır. $B$ yine bir kromozom olsun. Algoritmada geçen $d[i]$, rota ayrıtı $B[i]$ için maliyet etiketidir. pred $[i]$, rota ayrıtı $B[i]$ için uzaklık etiketine karşıllık gelen çevrimden bir önceki çevrimin son rota ayrıtıdır. Örneğin, YÇÇ'de (Şekil 4) pred [5] $=B[2]=1$ ve pred $[2]=B[0]=0$ olduğunda, $\{3,1\}$ ve $\{2,5,4\}$ çevrimleri oluşur. ol $[i, p]$ rota ayrıtı $B[i]$ 'nin mevcut etiketi pred[i] için $p$ gönderici firmasının rota paylaştığı gönderici firmalar kümesini ifade eder. olurlu( $i, j)$ fonksiyonu, $B[i+1], \ldots, B[j]$ çevrimi olurlu olduğunda 1 değerini, aksi halde 0 değerini verir. $c(i, j)$ fonksiyonu, $B[i+1], \ldots, B[j]$ çevriminin toplam maliyetini hesaplar. dao $(i, j)$ fonksiyonu, $B[i+$ $1], \ldots, B[j]$ çevrimi ile $B[j]$ düğümünün etiketinin oluşturulması halinde gönderici firmaların herhangi biri daha az ortak sahibi oluyorsa 1 , aksi halde 0 değerini verir. $g[i]$ ise, rota ayritı $B[i]$ 'nin ait olduğu gönderici firmayı ifade eder.

Etiket sabitleme algoritmasında, 1-2 hazırlık adımlarıdır. Adım 3'ün sonuna gelindiğinde, $B[i]$ rota ayrıtının bütün etiketleri $(d, p r e d, o l)$ sabitlenmektedir. Etiketlerin sabitlenme sırası rota ayrıtlarının kromozomdaki sırası ile aynıdır. Eğer $(B[i], B[j])$ olursuzluğa neden olacak bir çevrime karşılık geliyorsa; $\quad(B[i], B[j+$ $1]),(B[i], B[j+2]), \ldots$ ayrıtlarına karşıllk gelen çevrimleri, olurlu olmaları mümkün olmadığı için kontrol etmeye gerek yoktur. Bu nedenle, Adım 4'te olurlu $(i, j)=1$ değil ise Adım 3'e gidilir. Adım 5 'te $B[j]$ rota ayrıtının etiketlerinin güncellenmesine gerek olup olmadığ kontrol edilir. Etiketler, sadece daha düşük bir maliyet 
etiketi elde edilmesi veya aynı maliyete daha az sayıda ortak ile ulaşılması halinde güncellenirler. Adımlar 6-9, $B[j]$ rota ayrtının ol etiketinde $B[i+1], \ldots, B[j]$ çevrimindeki gönderici firmaların ortak listelerini güncellerler. Adımlar 10 ve 11, döngülerin tamamlanması içindirler. Algoritma sonlandığında, kromozomdaki son rota ayrıtının maliyet etiketi $d[|L|]$, kromozoma karşıllk gelen çözümün toplam maliyetini verir. Bu toplam maliyet, aynı zamanda kromozomun uygunluk değerinin -1 ile çarpılmış halidir. Çözümü oluşturan çevrimler pred $[|L|]$ 'den başlanarak diğer pred'ler yardımıyla geriye doğru gidilerek belirlenirler.

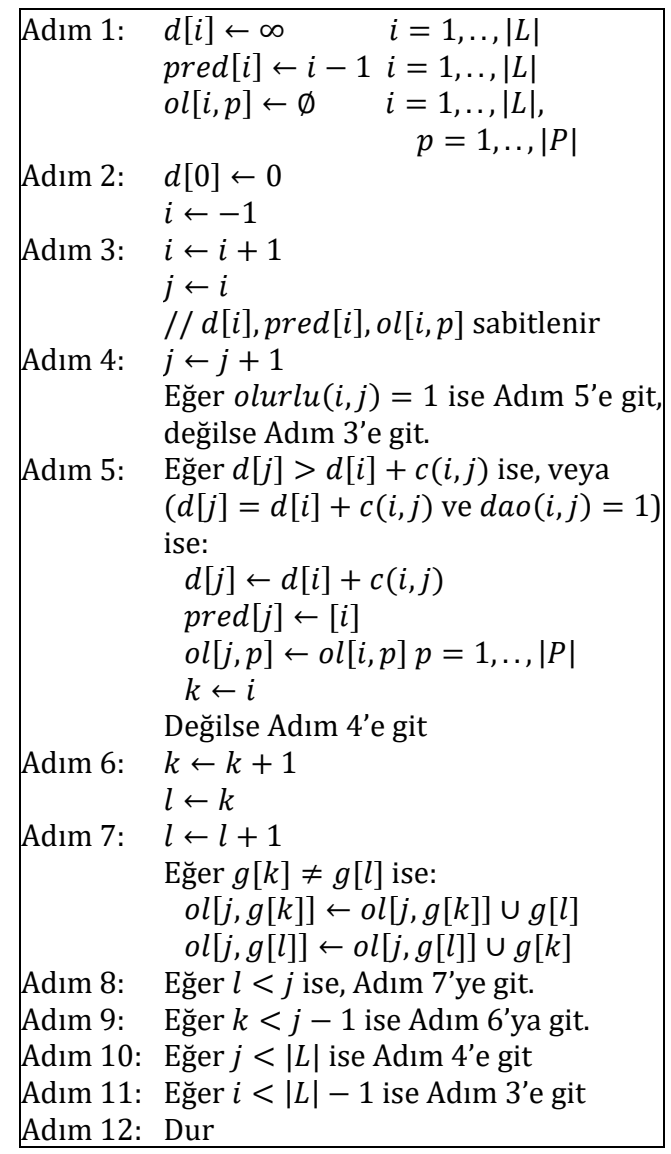

Şekil 7. Etiket sabitleme algoritmasının adımları

3.2. Popülasyon yapısı ve başlangıç popülasyonu

Popülasyon $p b$ adet kromozomdan oluşur. Başlangıç popülasyonu, $p b-1$ adet rastgele çözüm ve bütün rota ayrıtlarının tek başına olduğu en kötü olurlu çözümden oluşur. Bulunan en iyi çözümün bir kopyası (bei) popülasyon dışında yedeklenir ve farklı aşamalarda gerektiğinde popülasyona eklenir.

\subsection{Ebeveyn seçimi ve çaprazlama}

Ebeynlerin seçiminde ikili turnuva seçimi kullanılmaktadır. Popülasyondan dört adet ebeveyn adayı art arda rastgele seçilir. Birinci ve ikinci adaylar karşılaştırılır ve daha düşük maliyete sahip olan birinci ebeveyn olur. Aynı işlem üçüncü ve dördüncü adaylara da uygulanarak ikinci ebeveyn seçilir. Seçilen ebeveynler üzerinde OX çaprazlama (OX crossover) uygulanarak iki çocuk elde edilir. Çocuklardan eşit olasılıkla rastgele seçilen biri tutulur, diğeri ise silinir. Elde tutulan çocuk en iyi çözümden daha iyi ise bilinen en iyi çözüm güncellenir.

OX çaprazlama işlemi şu şekilde yapılır. Uzunlukları $|L|$ olan iki ebeveyn $E 1$ ve $E 2$ verilmiş olsun. İki pozisyon $i$ ve $j, 1 \leq i \leq j \leq|L|$ olacak şekilde rastgele belirlenir. Birinci çocuk C1'i elde etmek için, önce $E 1$ 'de $i, \ldots, j$ pozisyonlarındaki elemanlar $C 1$ 'in $i, \ldots, j$ pozisyonlarına kopyalanır, daha sonra E2 ebeveyni $j+1(\bmod |L|) \quad$ pozisyonundan başlanarak dairesel olarak taranır ve C1'de henüz yer almayan elemanlar C1[j]'nin sonrasina dairesel olarak $(\bmod |L|)$ eklenir. Aynı işlem $E 1$ ile $E 2, C 1$ ile de $C 2$ yer değiştirilerek tekrarlanır ve ikinci çocuk $C 2$ elde edilir. Şekil 8, HGA'da kullanılan OX çaprazlama işleminin bir örneğini göstermektedir. Yukarıda da belirtildiği gibi, $C 1$ ve $C 2$ 'den biri eşit olasıllkla rastgele silinir.

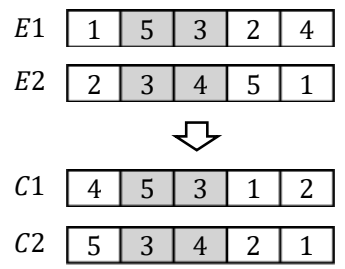

Şekil 8. OX çaprazlama örneği.

\subsection{Yerel arama}

Çaprazlama ile elde edilen çocuk, yao olasılıkla yerel aramaya tabi tutulur. $\mathrm{Bu}$ aşamada uygulanan yerel aramayı mutasyon olarak değerlendirmek mümkündür. Yerel arama, etiket sabitleme algoritması (bkz. 3.1) ile belirlenen çevrimleri açgözlü bir şekilde tekrar tekrar birleștirerek toplam maliyeti mümkün 
olduğu kadar küçültür. İki çevrimin birleștirilmesi ișlemi, bu çevrimlerin en uzun boș hareket ayrıtlarının silinip ortaya çıkan iki adet yönlü yolun uç noktalarının (gerekirse yeni boș hareket ayrıtları eklenerek) tek bir çevrim oluşturacak șekilde birleștirilmesi ile yapılır. Yerel aramanın her iterasyonunda, en yüksek iyileşmeyi sağlayan birleştirme yapılır. Sadece olurluluğu koruyan ve maliyeti azaltan birleștirmelere izin verilmektedir. Şekil 9, birleștirme işlemi için bir örnek göstermektedir.
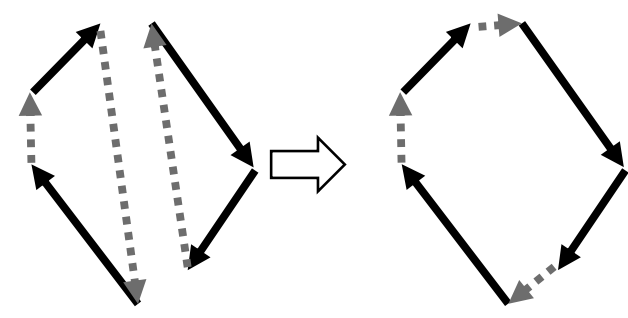

Şekil 9. Yerel aramada yapılan birleștirme işlemi örneği.

\subsection{Geniş komşuluk arama}

Mevcut popülasyondaki bireylerin her biri üzerinde tahrip ve tamir operasyonları gerçekleștirilir. Tahrip operasyonunda kromozomun elemanları üzerinden sırayla geçilir. Her bir eleman, eğer hâlihazırda tek bașına bir çevrim olușturmuyorsa, to olasılıkla tek başına bir çevrim yapılır, varsa bu elemandan bir sonraki eleman ile yeni bir çevrime başlanır. Bu işlemle bir çevrim iki veya üç ayrı çevrime bölünmüş olur. Örneğin; bir kromozomda 1-2-3-4-5 rota ayritı dizisi bir çevrime karşılık gelsin. Tahrip operasyonu:(a) 1 üzerinde yapılırsa, 1 ve 2-3-4-5 olarak iki çevrim; (b) 3 üzerinde yapılırsa, 1-2, 3 e 4-5 olmak üzere üç çevrim; (c) 5 üzerinde yapılırsa, 1-2-3-4 ve 5 olmak üzere iki çevrim ortaya çlkar. Bu operasyon çözümün olurluluğunu korur. Tahrip edilen çözüm, Bölüm 3.4'te tarif edilen yerel arama algoritması ile tamir edilir. Tamir sonrasında elde edilen çözümlerden herhangi biri bulunan en iyi çözümden daha iyi ise bilinen en iyi çözüm güncellenir.

\subsection{Yeni neslin seçimi}

Tahrip ve tamir operasyonları mevcut popülasyonda değișikliğe neden olur, ancak popülasyondaki birey sayısı değișmez. Değişmiş popülasyondaki çözümler maliyetlerine göre küçükten büyüğe sıralanır. Ortanca çözümden sonraki çözümlerden biri rastgele seçilir. Çaprazlama (ve yeral arama) ile elde edilen çocuk, aynı maliyete sahip başka bir çözüm olmaması halinde seçilen çözümle yer değiștirir.

\subsection{Durma koşulları}

MGA'da önce bașlangıç popülasyonu olușturulur. Daha sonra, 3.2 - 3.6 başlıklarında tanımlanan işlemler durma koşulları sağlanıncaya kadar tekrarlanır. Belirli sayıda (mns) nesil oluşturulduğunda veya bilinen en iyi çözümde iyileştirme görülmeyen nesil sayısı belirli bir sayıya (mions) ulaştığında algoritma sonlanır.

\section{Deneysel Çalışmalar}

Geliștirilen MGA'nın performansı, elde ettiği çözümleri Kuyzu[3] tarafından geliştirilen sütun türetme ve dal-fiyat yöntemleri ve yine aynı makaledeki deneysel çalışmalarda mihenk taşı olarak kullanılan kaba kuvvet çözüm yaklaşımları ile elde edilen çözümlerle karşılaştırmak suretiyle ölçülmüştür. Sağlıklı bir karşılaştırma olması için aynı örnekler ve parametre değerleri kullanılmıştır. Örnekler, Öklid uzaklıklarına sahiptir, ve belirli kurallara göre rastgele üretilmişlerdir. Bu örneklerde rota ayrıtları $1800 \mathrm{~km} \times 1800 \mathrm{~km}$ bir alana dağıtılmış düğümler arasındadırlar. Örnekler, büyük şehirlerin coğrafi yoğunluklarına karşıllık gelen düğüm kümelenmeleri (cluster) içermektedir. Ayrıca; tedarikçi, depo ve müşteriler olmak üç ayrı tip düğüm bulunmaktadır. Rota ayrıtları sadece tedarikçi-depo, depo-depo ve depomüșteri düğüm tipleri arasında olmaktadır. Rota ayrıtlarının başlangıç ve bitiş düğümlerinin aynı kümelenme içerisinde olmalarına izin verilmemektedir.

Örnekler türetilirken çeşitlilik olması için farklı düğüm sayısı, kümelenmelerdeki düğümlerin oranı, rota ayrıtlarının sayıları, gönderici sayıları, göndericilere ait rota sayıları ve ortak kısıtları kullanılmıştır. İçerisindeki nokta sayısı ve rota ayrıtlarının sayısı çeşitlilik göstermektedir. Örnekler; 100 veya 200 düğüm, için 0.5 ile 0.8 arasında değişen kümelenme oranı (KDO) ve her kümelenmede ortalama 10 düğüm olacak șekilde üretilmiștir. Rota ayrıtları; sayıları dügüm sayısına eşit veya iki katı olacak şekilde üretilmişlerdir. Büyük gönderici $(\operatorname{lgCo})$ ve küçük gönderici (smCo) olmak üzere iki ana örnek tipi vardır. Büyük gönderici örneklerinde her gönderici ortalama 20 rota ayrıtına sahiptir ve en fazla 1 veya 2 göndericiyle işbirliği yapmak istemektedir. Küçük gönderici örneklerinde ise 
her gönderici ortalama 10 rota ayrıtına sahiptir ve en fazla 3 veya 4 gönderici ile ișbirliği yapmak istemektedir. Her parametre konfigürasyonu için üç farklı rastgele sayı tohumu kullanılmış ve böylece her konfigürasyon için üç farklı örnek üretilmiştir. Toplamda ise 48 farklı örnek üretilmiş ve sayısal analizde kullanılmıștır. Üzerinde çalışılan problemler için geliştirilen çözüm yöntemleri denenirken RKP'lere ortak kısıtlarının yanında uzunluk $(T=3850 \mathrm{~km})$ ve sayı $(K=4)$ kısıtları uygulanmıştır.

Geliștirilen melez genetik algoritma, C++ programlama dilinde kodlanmıştır. Bütün sayisal analizler; 2 adet $2.00 \mathrm{GHz}$ Intel Xeon E52650 işlemcili, 128 GB RAM kapasiteli iş istasyonu üzerinde koșturulmuşlardır.

\subsection{Sonuçlar}

Melez genetik algoritma şu parametre değerleri ile koşturulmuştur:

$$
\begin{aligned}
& p b=8 \quad \text { (popülasyon büyüklüğü) } \\
& m n s=1000 \quad \text { (maksimum nesil sayısı) } \\
& \text { mions }=100 \text { (maksimum iyileștirme olmayan } \\
& \text { nesil sayısı) }
\end{aligned}
$$

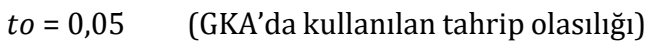

Bu parametre değerleri bir çok farklı değer sistematik olarak değerlendirildikten sonra belirlenmiștir. Algoritma, literatürde yer alan genetik algoritmalarla karșılaștırıldığında oldukça küçük bir popülasyon büyüklüğü ve az sayıda nesil ile çalışmaktadır.

MGA ile edilen sonuçların daha önce elde edilen sonuçlarla karşılaștırması Tablo 2'de yer almaktadır. Tabloda yer alan başlıkların açıklamaları așağıdadır. Tabloda geçen ST, DF ve KK çözüm yaklaşımları daha önce yapılan bir çalışmada[3] kullanılmışlardır ve tabloda yer alan değerler bahsi geçen çalıșmadan alınmışlardır. Amaç fonksiyonu değerleri, çok basamaklı büyük sayılar olmaları nedeniyle; problemin ortak, sayı ve uzunluk kısıtlarının içermeyen ve polinom zamanda çözülebilen RKP'nin en iyi çözümüne olan yüzde uzaklığı veya açıklığı olarak ifade edilmişlerdir. Tabloda eğik olarak yazılmış değerler bu çalıșma öncesindeki bilinen en iyi değerleri ifade ederken, koyu olarak yazılmıș değerler ise bu çalışma sayesinde elde edilen yeni en iyi değerleri ifade etmektedirler. Коуи ve ĕğik yazılmış değerler ise geçmiş çalıșmalarda elde edilen en iyi olup bu çalışma ile iyileștirilemeyen değerleri ifade ederler.

Örnek:Problem örneğinin kısa adı,

$|N|$ :Düğüm sayısı,

$|L| \quad$ :Rota ayrıtı sayısı,

KDO :Kümelenmiş düğüm oranı,

$|C(L)|$ :Tam enumerasyon ile edilen olurlu çevrim sayısı,

RKP :Problemin ortak, sayı, uzunluk kısıtları olmayan polinom zamanda çözülebilen gevşetmesi

MGA :Bu çalıșma kapsamında geliştirilen melez genetik algoritma,

ST :Sütun türetme ile doğrusal gevşetmeyi çözdükten sonra eldeki sütunlar ile tam sayılı çözüm elde eden yaklaşım,

DF :Dal-fiyat algoritması,

KK :Kaba kuvvet yaklaşımı: $C(L)^{\prime}$ deki bütün çevrimleri üreterek tam sayılı program çözme,

Tablo 2'de year alan "RKP Alt Sinırına Uzaklık (\%)" değerleri Șekil 10'da grafikler halinde de sunulmaktadır. KK yöntemi ile smCo21 ve smCo24 örnekleri için elde edilen çözümlerin RKP alt sınırına uzaklıkları $\% 40,5$ ve $\% 50,9$ değerleridir. Diğer örnekler için herhangi bir yöntem ile elde edilen çözümlerin tamamının RKP alt sınırına uzaklıkları \%16'nın altındadır. Yorumlamada kolaylık sağlamak için Şekil 10 'daki bütün grafiklerde y-ekseni $\% 0$ ve $\% 16$ değerleri arasında sabitlenmiștir. Bunun sonucunda KK yönteminin smCo21 ve smCo24 örnekleri için bulduğu sonuçların RKP alt sınırına uzaklıklarının sadece \%16'lık kısımları resmedilmiștir. Tablo 2 ve Şekil 10 incelendiğinde, MGA'nın 400 rota ayrıtı içeren örneklerin tamamında daha önceki bulunan çözümlerden daha iyi çözümler elde ettiği görülmektedir. Diğer örneklerde ise ST 
yaklaşımından daha iyi çözüm elde etmekte, fakat DF veya KK yaklaşımlarından daha iyi çözüm elde edememektedir. Bütün problem örneklerinde düğümler ve rotalar aynı büyüklükteki $(1800 \mathrm{~km} \times 1800 \mathrm{~km})$ bir alan üzerinde olușturulmaktadır. Rota sayısı arttığında rota yoğunluğu da bir anlamda artmaktadır. Rota yoğunluğu arttığında olurlu çözüm bulmak kolaylaşmaktadır. Küçük değişiklerle bir olurlu çözümden diğerine gitmek kolaylaşmaktadır. Düşük yoğunluklu problem örneklerinde bir olurlu çözümden diğerine gitmek, bir yerel en iyiden diğerine gitmek, daha büyük değișiklikler gerektirmekte ve zorlaşmaktadır. Çalıșılan problemin ayırt edici özelliği olan ortak kısıtlarının çevrimler arası kapsamda sınırlayıcı olması bir olurlu çözümden diğerine gitmeyi daha da zorlaştırmaktadır. Rota sayısı ve yoğunluğu arttığında problem ölçeği hızla büyümekte, DF ve KK yaklaşımlarının performansı da düşmektedir. Bu düşüşte her ikisine de uygulanan zaman sinırı ve KK yaklaşımının yüksek bellek ihtiyacı önemli rol oynamaktadır. MGA'nın performansı (daha fazla) artmasa de DF ve KK yaklaşımlarının performansı (daha fazla) azaldığı için, rota sayısı ve yoğunluğu arttığında MGA onlardan daha iyi sonuçlar elde etmektedir.

Tablo 2 koșturum zamanları açısından incelendiğinde, DF veya KK yaklaşımlarına göre daha kısa sürede koșmakta, ST yaklașımından ise daha uzun veya kısa sürede koşabilmektedir. Sonuçlar incelendiğinde kesin en iyi çözüme ulaşmanın zor olduğu anlaşılmaktadır. MGA'nın özellikle rota ayrıtı sayısının ve yoğunluğunun fazla olduğu örneklerde etkin bir alternatif olacağı değerlendirilmektedir.

Melez yaklaşımın kattığı değeri ortaya koymak amacıyla, MGA iki saf (melez olmayan) yaklaşımla karşılaștırılmıștır. Birinci saf yaklaşım sadece GA mekanizmasını kullanan, yani GKA kullanmayan, bir yaklaşımdır. İkinci saf yaklașım ise sadece GKA kullanan, yani çaprazlama ve mutasyon gibi GA ișlemlerini kullanmayan, bir yaklaşımdır. İlgili deneyin sonuçları Tablo 3'te yer almaktadır. Üç örnek (lgCo16, lgCo24, smCo6) dışında bütün örnekler için en iyi sonuçlar melez yaklașım ile elde edilmektedir. Sadece GKA kullanmanın en yüksek maliyetli sonuçları verdiği görülmektedir. Öte yandan, sadece GKA kullanıldığında algoritma kısa sürede sonlanmaktadır. Bunun temel nedeni, sadece
GKA yaklaşımının az sayıda nesil sonunda durmasıdır. $\mathrm{Bu}$ da bilinen en iyi çözümü değiştirmekte zorlanmasından kaynaklanmaktadır. Sadece GA yaklaşımı amaç fonksiyonu açısından daha iyi sonuçlar vermektedir, ancak koşturum zamanları sadece GKA yaklaşımına göre çok daha uzundurlar. Burada koşturum zamanını uzatan unsurun çözülmesi gereken kaynak kısıtlı en kısa yol problemi olduğu düşünülmektedir. Öte yandan, çaprazlama sonra yerel aramada çok daha fazla olurlu alternatif ortaya çıkması ihtimali de vardır. $\mathrm{Bu}$ sonuçlar, melez yaklaşımın algoritmanın daha yüksek kalitede çözümleri bulmada etkin olduğunu ortaya koymaktadır.

\section{Sonuç ve Değerlendirme}

$\mathrm{Bu}$ çalışmada, tam kamyon yükü hizmeti satın alma işbirliği ağlarında ortaya çıkan NP-Zor bir eniyileme problemi olan OKRKP'nin ve bazı varyantlarının çözümüne yönelik, genetik algoritma ve geniș komșuluk arama yaklaşımlarını birleştiren MGA yaklaşımı geliștirilmiștir. MGA, herhangi bir NP-Zor RKP varyantı için geliștirilmiş ilk meta-sezgiseldir.

MGA'nın performansı, literatürde kullanılan problem örnekleri üzerinde denenmiş ve literatürde yer alan sonuçlarla karşılaştırılmıştır. Deney sonuçlarına göre, özellikle büyük ölçekli problem örneklerine yüksek kaliteli çözümler elde etmek için etkin bir alternatif olduğu görülmektedir. Öte yandan, küçük ölçekli örneklerinde, daha önce kullanılan kesin çözüm yöntemlerine (DF, KK) çok yakın bir performans gösterse de, bilinen en iyi çözümlerin gerisinde çözümler elde etmektedir. $\mathrm{Bu}$ durumun, OKRKP'nin ayırt edici özelliği olan ortak kısıtları nedeniyle bir olurlu çözümden diğerine küçük değişikliklerle ulaşmanın zorluğundan kaynaklandığı değerlendirilmektedir. Elde edilen sonuçlar, çalışılan problemin kesin en iyi çözümlerinin bulunmasının zorluğunu ortaya koymaktadır.

\section{Kaynakça}

[1] Ergun, Ö., Kuyzu, G., Savelsbergh, M., 2007. Shipper collaboration. Computers \& Operations Research, 34, 1551-1560.

[2] Ergun, Ö., Kuyzu, G., Savelsbergh, M., 2007. Reducing Truckload Transportation Costs Through Collaboration. Transportation Science 41, 206-221.

[3] Kuyzu, G., 2017. Lane covering with partner bounds in collaborative truckload transportation procurement. Computers \& Operations Research 77, 32-43. 
DEÜ FMD 22(65), 401-416, 2020

[4] Clarke, G. and Wright, J.W., 1964. Scheduling of vehicles from a central depot to a number of delivery points. Operations research, 12(4), pp.568-581.

[5] Immorlica, N., Mahdian, M., Mirrokni, V.S., 2005. Cycle Cover with Short Cycles, in: Diekert, V., Durand, B. (Eds.), STACS 2005, Lecture Notes in Computer Science. Springer Berlin Heidelberg, pp. 641-653.

[6] Thomassen, C., 1997. On the complexity of finding a minimum cycle cover of a graph. SIAM Journal on Computing 26, 675-677.

[7] Hochbaum, D. S. , Olinick, V., 2001. The bounded cycle-cover problem, INFORMS Journal on Computing, 13(2), 104-119.

[8] Fernandes, C.G., Lee, O., Wakabayashi, Y., 2009. Minimum cycle cover and Chinese postman problems on mixed graphs with bounded tree-width Discrete Applied Mathematics 157, 272-279.

[9] Golden, B.L., Wong, R.T., 1981. Capacitated arc routing problems. Networks 11, 305-315.

[10] Corberán, A., Prins, C., 2010. Recent results on Arc Routing Problems: An annotated bibliography. Networks 56, 50-69.

[11] Moscato, P., Cotta, C., 2010. A Modern Introduction to Memetic Algorithms, in: Gendreau, M., Potvin, J.-Y. (Eds.), Handbook of Metaheuristics, International Series in Operations Research \& Management Science. Springer US, Boston, MA, pp. 141-183.

[12] Lacomme, P., Prins, C., Ramdane-Cherif, W., 2004. Competitive Memetic Algorithms for Arc Routing Problems. Ann Oper Res 131, 159-185.

[13] Prins, C., 2004. A simple and effective evolutionary algorithm for the vehicle routing problem Computers \& Operations Research 31, 1985-2002.

[14] Prins, C., 2009. Two memetic algorithms for heterogeneous fleet vehicle routing problems.
Engineering Applications of Artificial Intelligence, Artificial Intelligence Techniques for Supply Chain Management 22, 916-928.

[15] Liu, R., Jiang, Z., Liu, X., Chen, F, 2010. Task selection and routing problems in collaborative truckload transportation. Transportation Research Part E: Logistics and Transportation Review 46, 1071-1085.

[16] Chen, Y., Hao, J.-K., Glover, F., 2016. A hybrid metaheuristic approach for the capacitated arc routing problem. European Journal of Operational Research 253, 25-39.

[17] Arakaki, R.K., Usberti, F.L., 2018. Hybrid genetic algorithm for the open capacitated arc routing problem. Computers \& Operations Research 90, 221-231.

[18] Tirkolaee, E.B., Hosseinabadi, A.A.R., Soltani, M., Sangaiah, A.K., Wang, J., 2018. A Hybrid Genetic Algorithm for Multi-Trip Green Capacitated Arc Routing Problem in the Scope of Urban Services. Sustainability 10, 1366.

[19] Hiermann, G., Hartl, R.F., Puchinger, J., Vidal, T., 2019. Routing a mix of conventional, plug-in hybrid, and electric vehicles. European Journal of Operational Research 272, 235-248.

[20] G. Ulusoy, "The fleet size and mix problem for capacitated arc routing", European Journal of Operational Research, 22(3), 329-337, 1985.

[21] Pisinger, D., Ropke, S., 2010. Large Neighborhood Search, in: Gendreau, M., Potvin, J.-Y. (Eds.), Handbook of Metaheuristics, International Series in Operations Research \& Management Science. Springer US, Boston, MA, pp. 399-419.

[22] Pugliese, L.D.P., Guerriero, F., 2013. A survey of resource constrained shortest path problems: Exact solution approaches. Networks 62, 183-200. 
DEÜ FMD 22(65), 401-416, 2020

Tablo 2. Geliştirilen Melez Genetik Algoritmanın (MGA) örnekler üzerinde karşılaştırmalı sonuçları

\begin{tabular}{|c|c|c|c|c|c|c|c|c|c|c|c|c|c|}
\hline \multirow[b]{2}{*}{ Örnek } & \multirow[b]{2}{*}{$|N|$} & \multirow[b]{2}{*}{$|L|$} & \multirow[b]{2}{*}{ KDO } & \multirow[b]{2}{*}{$|P|$} & \multirow[b]{2}{*}{$|C(L)|$} & \multicolumn{4}{|c|}{ RKP Alt Sınırına Uzaklık (\%) } & \multicolumn{4}{|c|}{ Koșturum Zamanı (sn) } \\
\hline & & & & & & MGA & ST & $\mathrm{DF}$ & $\mathrm{KK}$ & MGA & ST & DF & KK \\
\hline $\operatorname{lgCo1}$ & 100 & 100 & 0,5 & 5 & 54.080 & 8,8 & 9,0 & 6,0 & 5,9 & 26 & 34 & 118 & 35 \\
\hline $\lg \mathrm{Co} 2$ & 100 & 100 & 0,5 & 5 & 161.643 & 4,6 & 4,6 & 2,4 & 2,2 & 33 & 30 & 136 & 341 \\
\hline $\lg \mathrm{Co} 3$ & 100 & 100 & 0,5 & 5 & 98.669 & 7,9 & 10,6 & 6,0 & 5,3 & 24 & 35 & 155 & 136 \\
\hline $\lg \mathrm{Co} 4$ & 100 & 100 & 0,8 & 5 & 48.095 & 3,2 & 4,5 & 1,9 & 1,7 & 13 & 6 & 45 & 71 \\
\hline $\lg \operatorname{Co} 5$ & 100 & 100 & 0,8 & 5 & 171.515 & 4,4 & 7,5 & 3,3 & 3,2 & 23 & 19 & 156 & 417 \\
\hline $\lg \operatorname{Co} 6$ & 100 & 100 & 0,8 & 5 & 165.902 & 4,1 & 8,7 & 1,9 & 1,5 & 8 & 10 & 68 & 438 \\
\hline $\lg \mathrm{Co} 7$ & 100 & 200 & 0,5 & 10 & 349.555 & 6,3 & 9,1 & 4,4 & 4,2 & 340 & 111 & 10.911 & 5.533 \\
\hline $\lg \operatorname{Co} 8$ & 100 & 200 & 0,5 & 10 & 319.664 & 7,1 & 8,4 & 4,2 & 3,9 & 192 & 229 & 11.030 & 3.509 \\
\hline $\lg \operatorname{Co} 9$ & 100 & 200 & 0,5 & 10 & 528.574 & 9,5 & 15,4 & 4,7 & 4,6 & 161 & 149 & 3.301 & 3.614 \\
\hline $\lg \mathrm{Co} 10$ & 100 & 200 & 0,8 & 10 & 2.008 .740 & 3,7 & 6,4 & 2,2 & & 321 & 86 & 8.998 & \\
\hline $\lg \mathrm{Co} 11$ & 100 & 200 & 0,8 & 10 & 11.308 .995 & 2,3 & 3,7 & 0,9 & & 121 & 68 & 10.868 & \\
\hline $\lg \mathrm{Co} 12$ & 100 & 200 & 0,8 & 10 & 2.007 .288 & 6,5 & 9,0 & 3,2 & & 115 & 40 & 7.558 & \\
\hline $\lg \mathrm{Co} 13$ & 200 & 200 & 0,5 & 10 & 588.131 & 7,3 & 10,2 & 4,9 & 4,3 & 156 & 216 & 11.016 & 24.176 \\
\hline $\operatorname{lgCo} 14$ & 200 & 200 & 0,5 & 10 & 393.369 & 8,4 & 9,4 & 5,5 & 5,2 & 168 & 362 & 11.162 & 4.136 \\
\hline $\operatorname{lgCo} 15$ & 200 & 200 & 0,5 & 10 & 2.524 .376 & 6,0 & 7,8 & 4,1 & & 515 & 578 & 11.378 & \\
\hline $\operatorname{lgCo} 16$ & 200 & 200 & 0,8 & 10 & 838.434 & 9,4 & 13,2 & 3,4 & 3,3 & 167 & 251 & 11.051 & 29.068 \\
\hline $\lg \mathrm{Co} 17$ & 200 & 200 & 0,8 & 10 & 341.145 & 10,0 & 14,9 & 7,7 & 7,7 & 201 & 136 & 9.152 & 1.873 \\
\hline $\lg \mathrm{Co} 18$ & 200 & 200 & 0,8 & 10 & 603.133 & 11,7 & 14,2 & 7,9 & 7,6 & 243 & 388 & 10.447 & 5.282 \\
\hline $\operatorname{lgCo} 19$ & 200 & 400 & 0,5 & 20 & 9.419 .479 & 7,8 & 10,8 & 10,8 & & 5.148 & 3.118 & 13.925 & \\
\hline $\lg \mathrm{Co} 20$ & 200 & 400 & 0,5 & 20 & 5.326 .397 & 10,6 & 12,7 & 12,7 & & 3.313 & 3.284 & 14.109 & \\
\hline $\operatorname{lgCo} 21$ & 200 & 400 & 0,5 & 20 & 14.422 .985 & 13,2 & 15,1 & 15,1 & & 1.291 & 2.264 & 13.064 & \\
\hline $\operatorname{lgCo} 22$ & 200 & 400 & 0,8 & 20 & 11.085 .224 & 10,7 & 13,1 & 13,1 & & 1.378 & 1.368 & 12.168 & \\
\hline $\operatorname{lgCo} 23$ & 200 & 400 & 0,8 & 20 & 5.775 .517 & 7,6 & 10,7 & 10,7 & & 5.719 & 1.301 & 12.115 & \\
\hline $\operatorname{lgCo} 24$ & 200 & 400 & 0,8 & 20 & 35.592 .361 & 11,9 & 14,4 & 14,4 & & 2.643 & 926 & 11.732 & \\
\hline smCo1 & 100 & 100 & 0,5 & 10 & 110.496 & 2,5 & 2,8 & 2,1 & 1,5 & 12 & 22 & 10.822 & 733 \\
\hline smCo2 & 100 & 100 & 0,5 & 10 & 61.989 & 2,5 & 3,6 & 1,3 & 0,9 & 13 & 24 & 10.824 & 607 \\
\hline smCo3 & 100 & 100 & 0,5 & 10 & 53.959 & 5,0 & 6,5 & 3,0 & 2,2 & 14 & 53 & 10.853 & 803 \\
\hline $\mathrm{smCo} 4$ & 100 & 100 & 0,8 & 10 & 108.405 & 2,3 & 4,5 & 1,0 & 0,4 & 24 & 19 & 10.819 & 3.344 \\
\hline smCo5 & 100 & 100 & 0,8 & 10 & 40.380 & 1,5 & 2,0 & 0,8 & 0,6 & 12 & 36 & 10.836 & 493 \\
\hline smCo6 & 100 & 100 & 0,8 & 10 & 261.260 & 1,8 & 2,6 & 0,7 & 0,5 & 23 & 20 & 10.820 & 7.780 \\
\hline smCo7 & 100 & 200 & 0,5 & 20 & 468.782 & 5,6 & 7,0 & 5,9 & 6,2 & 191 & 84 & 10.884 & 21.369 \\
\hline smCo8 & 100 & 200 & 0,5 & 20 & 3.568 .824 & 4,1 & 4,2 & 2,7 & 4,1 & 255 & 257 & 11.057 & 25.680 \\
\hline smCo9 & 100 & 200 & 0,5 & 20 & 674.404 & 4,1 & 4,9 & 4,9 & 2,7 & 172 & 251 & 11.052 & 27.163 \\
\hline smCo10 & 100 & 200 & 0,8 & 20 & 439.225 & 3,7 & 4,5 & 3,5 & 2,2 & 215 & 72 & 10.872 & 22.540 \\
\hline smCo11 & 100 & 200 & 0,8 & 20 & 444.302 & 3,4 & 4,1 & 2,4 & 2,3 & 126 & 115 & 10.915 & 22.018 \\
\hline smCo12 & 100 & 200 & 0,8 & 20 & 753.199 & 3,5 & 3,1 & 2,1 & 1,8 & 110 & 93 & 10.894 & 29.981 \\
\hline smCo13 & 200 & 200 & 0,5 & 20 & 763.147 & 8,8 & 9,5 & 9,3 & 9,7 & 198 & 293 & 11.093 & 31.786 \\
\hline smCo14 & 200 & 200 & 0,5 & 20 & 490.136 & 8,9 & 9,5 & 9,5 & 8,4 & 200 & 378 & 11.178 & 25.530 \\
\hline smCo15 & 200 & 200 & 0,5 & 20 & 1.788 .420 & 6,9 & 7,1 & 6,4 & 6,7 & 191 & 308 & 11.153 & 23.787 \\
\hline smCo16 & 200 & 200 & 0,8 & 20 & 1.289 .473 & 7,7 & 7,7 & 6,6 & 6,4 & 188 & 211 & 11.011 & 23.692 \\
\hline smCo17 & 200 & 200 & 0,8 & 20 & 1.008 .738 & 7,1 & 8,4 & 5,8 & 5,6 & 79 & 246 & 11.046 & 28.837 \\
\hline smCo18 & 200 & 200 & 0,8 & 20 & 569.332 & 4,2 & 6,9 & 5,1 & 3,4 & 215 & 296 & 11.096 & 24.068 \\
\hline smCo19 & 200 & 400 & 0,5 & 40 & 18.938 .902 & 9,8 & 11,2 & 11,2 & & 3.060 & 5.561 & 16.362 & \\
\hline smCo20 & 200 & 400 & 0,5 & 40 & 24.052 .909 & 10,1 & 10,9 & 10,9 & & 2.257 & 2.866 & 13.671 & \\
\hline smCo21 & 200 & 400 & 0,5 & 40 & 15.123 .974 & 10,5 & 11,4 & 11,4 & 50,9 & 2.044 & 7.080 & 17.881 & 24.067 \\
\hline $\mathrm{smCo} 22$ & 200 & 400 & 0,8 & 40 & 4.192 .305 & 6,2 & 10,3 & 10,3 & 10,3 & 2.538 & 999 & 11.806 & 33.679 \\
\hline smCo23 & 200 & 400 & 0,8 & 40 & 6.878 .146 & 6,7 & 7,8 & 7,8 & 9,7 & 1.361 & 5.133 & 15.934 & 31.732 \\
\hline smCo24 & 200 & 400 & 0,8 & 40 & 11.005 .317 & 9,7 & 10,6 & 10,6 & 40,5 & 1.512 & 2.997 & 13.798 & 22.121 \\
\hline
\end{tabular}


DEÜ FMD 22(65), 401-416, 2020
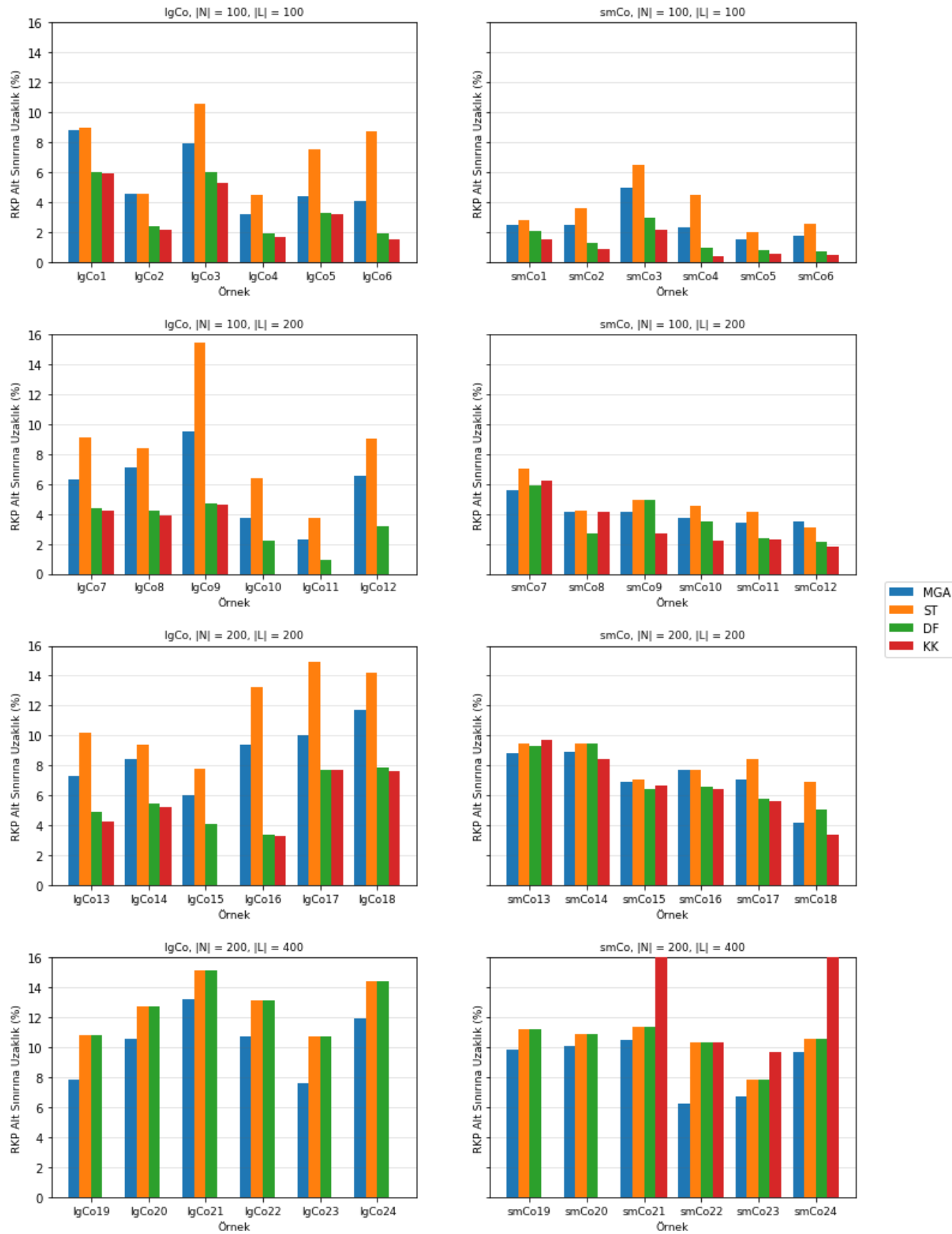

Şekil 10. Örnekler üzerinde MGA ve diğer yöntemlerle elde edilen çözümlerin RKP alt sınırına uzaklıkları 
DEÜ FMD 22(65), 401-416, 2020

Tablo 3. Melez yaklaşım ile saf yaklaşımların karşılaştırmalı sonuçları.

\begin{tabular}{|c|c|c|c|c|c|c|c|c|c|c|c|c|c|}
\hline \multirow[b]{2}{*}{ Örnek } & \multirow[b]{2}{*}{$|N|$} & \multirow[b]{2}{*}{$|L|$} & \multirow[b]{2}{*}{$K D O$} & \multirow[b]{2}{*}{$|P|$} & \multicolumn{3}{|c|}{$\begin{array}{l}\text { RKP Alt Sinırına } \\
\text { Uzaklık (\%) }\end{array}$} & \multicolumn{3}{|c|}{$\begin{array}{l}\text { Koşturum } \\
\text { Zamanı (sn) }\end{array}$} & \multicolumn{3}{|c|}{ Nesil sayısı } \\
\hline & & & & & MGA & $\begin{array}{l}\text { Sadece } \\
\text { GA }\end{array}$ & $\begin{array}{l}\text { Sadece } \\
\text { GKA }\end{array}$ & MGA & $\begin{array}{l}\text { Sadece } \\
\text { GA }\end{array}$ & $\begin{array}{l}\text { Sadece } \\
\text { GKA }\end{array}$ & MGA & $\begin{array}{l}\text { Sadece } \\
\text { GA }\end{array}$ & $\begin{array}{c}\text { Sadece } \\
\text { GKA }\end{array}$ \\
\hline $\lg \operatorname{lo} 1$ & 100 & 100 & 0,5 & 5 & 8,8 & 8,9 & 13,2 & 26 & 19 & 1 & 131 & 129 & 105 \\
\hline $\operatorname{lgCo} 2$ & 100 & 100 & 0,5 & 5 & 4,6 & 5,6 & 7,8 & 33 & 12 & 1 & 258 & 108 & 106 \\
\hline $\operatorname{lgCo3}$ & 100 & 100 & 0,5 & 5 & 7,9 & 10,4 & 13,4 & 24 & 16 & 2 & 233 & 185 & 193 \\
\hline $\operatorname{lgCo} 4$ & 100 & 100 & 0,8 & 5 & 3,2 & 4,5 & 10,5 & 13 & 13 & 1 & 217 & 214 & 115 \\
\hline $\lg \mathrm{Co} 5$ & 100 & 100 & 0,8 & 5 & 4,4 & 5,9 & 15,0 & 23 & 10 & 1 & 192 & 127 & 107 \\
\hline $\operatorname{lgCo6}$ & 100 & 100 & 0,8 & 5 & 4,1 & 5,1 & 11,1 & 8 & 9 & 1 & 145 & 143 & 118 \\
\hline $\operatorname{lgCo7}$ & 100 & 200 & 0,5 & 10 & 6,3 & 6,9 & 11,4 & 340 & 493 & 7 & 365 & 670 & 106 \\
\hline $\lg \operatorname{Co} 8$ & 100 & 200 & 0,5 & 10 & 7,1 & 8,4 & 9,4 & 192 & 111 & 7 & 322 & 202 & 106 \\
\hline $\lg \operatorname{Co} 9$ & 100 & 200 & 0,5 & 10 & 9,5 & 11,1 & 12,9 & 161 & 104 & 7 & 169 & 138 & 107 \\
\hline $\operatorname{lgCo} 10$ & 100 & 200 & 0,8 & 10 & 3,7 & 4,3 & 6,6 & 321 & 211 & 9 & 282 & 186 & 107 \\
\hline $\operatorname{lgCo} 11$ & 100 & 200 & 0,8 & 10 & 2,3 & 3,6 & 3,1 & 121 & 58 & 7 & 205 & 110 & 118 \\
\hline $\operatorname{lgCo} 12$ & 100 & 200 & 0,8 & 10 & 6,5 & 6,7 & 8,5 & 115 & 238 & 6 & 119 & 302 & 108 \\
\hline $\operatorname{lgCo13}$ & 200 & 200 & 0,5 & 10 & 7,3 & 8,8 & 10,9 & 156 & 99 & 7 & 219 & 174 & 116 \\
\hline $\operatorname{lgCo} 14$ & 200 & 200 & 0,5 & 10 & 8,4 & 8,9 & 11,4 & 168 & 198 & 7 & 149 & 267 & 106 \\
\hline $\operatorname{lgCo} 15$ & 200 & 200 & 0,5 & 10 & 6,0 & 6,8 & 9,0 & 515 & 117 & 8 & 383 & 127 & 106 \\
\hline $\operatorname{lgCo} 16$ & 200 & 200 & 0,8 & 10 & 9,4 & 9,4 & 12,9 & 167 & 133 & 7 & 207 & 189 & 111 \\
\hline $\lg \operatorname{Co} 17$ & 200 & 200 & 0,8 & 10 & 10,0 & 11,9 & 15,9 & 201 & 501 & 9 & 196 & 500 & 129 \\
\hline $\operatorname{lgCo18}$ & 200 & 200 & 0,8 & 10 & 11,7 & 12,5 & 13,3 & 243 & 213 & 12 & 218 & 186 & 152 \\
\hline $\operatorname{lgCo} 19$ & 200 & 400 & 0,5 & 20 & 7,8 & 9,2 & 11,7 & 5.148 & 2.401 & 68 & 555 & 286 & 101 \\
\hline $\lg \mathrm{Co} 20$ & 200 & 400 & 0,5 & 20 & 10,6 & 11,4 & 13,7 & 3.313 & 1.566 & 64 & 219 & 145 & 101 \\
\hline $\lg \mathrm{Co} 21$ & 200 & 400 & 0,5 & 20 & 13,2 & 13,7 & 15,7 & 1.291 & 1.459 & 91 & 117 & 152 & 100 \\
\hline $\lg \mathrm{Co} 22$ & 200 & 400 & 0,8 & 20 & 10,7 & 11,6 & 13,3 & 1.378 & 1.970 & 73 & 165 & 294 & 100 \\
\hline $\operatorname{lgCo} 23$ & 200 & 400 & 0,8 & 20 & 7,6 & 9,8 & 10,9 & 5.719 & 1.539 & 97 & 511 & 167 & 103 \\
\hline $\operatorname{lgCo} 24$ & 200 & 400 & 0,8 & 20 & 11,9 & 11,4 & 14,0 & 2.643 & 1.824 & 86 & 239 & 174 & 107 \\
\hline smCo1 & 100 & 100 & 0,5 & 10 & 2,5 & 4,4 & 7,3 & 12 & 7 & 1 & 243 & 179 & 131 \\
\hline smCo2 & 100 & 100 & 0,5 & 10 & 2,5 & 3,4 & 4,0 & 13 & 9 & 5 & 228 & 197 & 409 \\
\hline smCo3 & 100 & 100 & 0,5 & 10 & 5,0 & 6,4 & 13,0 & 14 & 15 & 1 & 276 & 354 & 115 \\
\hline smCo4 & 100 & 100 & 0,8 & 10 & 2,3 & 3,3 & 11,9 & 24 & 11 & 1 & 497 & 307 & 111 \\
\hline smCo5 & 100 & 100 & 0,8 & 10 & 1,5 & 2,7 & 4,8 & 12 & 9 & 1 & 202 & 216 & 126 \\
\hline smCo6 & 100 & 100 & 0,8 & 10 & 1,8 & 1,8 & 4,9 & 23 & 17 & 1 & 422 & 463 & 127 \\
\hline smCo7 & 100 & 200 & 0,5 & 20 & 5,6 & 7,5 & 8,2 & 191 & 123 & 22 & 384 & 334 & 344 \\
\hline smCo8 & 100 & 200 & 0,5 & 20 & 4,1 & 4,5 & 8,3 & 255 & 104 & 21 & 477 & 290 & 293 \\
\hline smCo9 & 100 & 200 & 0,5 & 20 & 4,1 & 4,5 & 6,4 & 172 & 113 & 16 & 360 & 318 & 229 \\
\hline smCo10 & 100 & 200 & 0,8 & 20 & 3,7 & 5,0 & 7,4 & 215 & 125 & 11 & 429 & 349 & 188 \\
\hline smCo11 & 100 & 200 & 0,8 & 20 & 3,4 & 3,7 & 6,1 & 126 & 120 & 18 & 268 & 338 & 264 \\
\hline smCo12 & 100 & 200 & 0,8 & 20 & 3,5 & 3,8 & 6,1 & 110 & 76 & 13 & 249 & 228 & 216 \\
\hline smCo13 & 200 & 200 & 0,5 & 20 & 8,8 & 9,6 & 16,5 & 198 & 117 & 14 & 384 & 275 & 168 \\
\hline smCo14 & 200 & 200 & 0,5 & 20 & 8,9 & 10,8 & 15,9 & 200 & 157 & 18 & 357 & 369 & 216 \\
\hline smCo15 & 200 & 200 & 0,5 & 20 & 6,9 & 8,2 & 14,0 & 191 & 166 & 10 & 386 & 468 & 158 \\
\hline smCo16 & 200 & 200 & 0,8 & 20 & 7,7 & 7,7 & 11,6 & 188 & 167 & 26 & 348 & 436 & 399 \\
\hline smCo17 & 200 & 200 & 0,8 & 20 & 7,1 & 8,2 & 9,8 & 79 & 66 & 14 & 146 & 168 & 248 \\
\hline smCo18 & 200 & 200 & 0,8 & 20 & 4,2 & 6,5 & 9,1 & 215 & 196 & 8 & 437 & 514 & 137 \\
\hline smCo19 & 200 & 400 & 0,5 & 40 & 9,8 & 11,4 & 14,1 & 3.060 & 1.548 & 112 & 511 & 352 & 174 \\
\hline smCo20 & 200 & 400 & 0,5 & 40 & 10,1 & 10,5 & 16,5 & 2.257 & 3.010 & 132 & 366 & 694 & 216 \\
\hline smCo21 & 200 & 400 & 0,5 & 40 & 10,5 & 11,1 & 16,8 & 2.044 & 1.389 & 143 & 347 & 338 & 257 \\
\hline smCo22 & 200 & 400 & 0,8 & 40 & 6,2 & 8,1 & 13,3 & 2.538 & 1.826 & 144 & 456 & 460 & 174 \\
\hline smCo23 & 200 & 400 & 0,8 & 40 & 6,7 & 8,3 & 10,6 & 1.361 & 857 & 130 & 234 & 200 & 207 \\
\hline smCo24 & 200 & 400 & 0,8 & 40 & 9,7 & 10,3 & 14,7 & 1.512 & 1.398 & 102 & 257 & 337 & 149 \\
\hline
\end{tabular}

